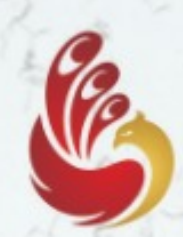

- L E M B AGA -

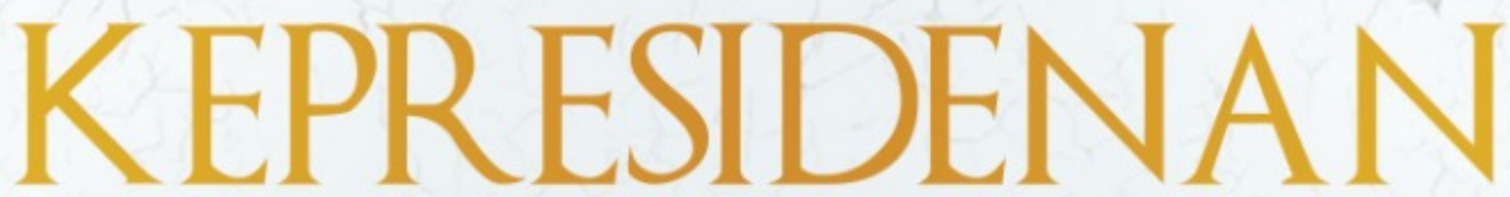

Sejarah dan Dinamika dalam Sistem Ketatanegaraan Indonesia 


\section{LEMBAGA KEPRESIDENAN}

Sejarah dan Dinamika dalam Sistem Ketatanegaraan Indonesia 
SEBAGIAN KEUNTUNGAN PENUALAN AKAN DIDONASIKAN UNTUK MENDUKUNG KEGIATAN SOSIAL DI INDONESIA

www.intranspublishing.com 


\section{Andryan, S.H., M.H.}

\section{LEMBAGA KEPRESIDENAN}

Sejarah dan Dinamika dalam Sistem Ketatanegaraan Indonesia

SetaraPress

2020 


\section{LEM BAGAKEPRESIDENAN}

\section{Sjarah dan Dinamikadalam Sstem Ketatanegaran Indonesia}

Penulis:

Andryan, S.H., M.H.

Cover: Rahardian Tegar Kusuma

Layout: Kamilia Sukmawati

Cetakan Pertama, Juli 2020

ISBN : 978-602-6344-98-4

Diterbitkan bersama oleh:

\section{Setara Press}

Kelompok Intrans Publishing

Wisma Kalimetro

J. Joyosuko Metro 42 Malang, Jatim

Telp. 0341-573650, Fax. 0341-573650

Email Pernaskahan: redaks.intrans@gmail.com

Email Pemasaran: intrans_malang@yahoo.com

Website: www.intranspublishing.com

AnggotalKAPI

Hak Cipta dilindungi oleh undang-undang. Dilarang mengutip atau memperbanyak baik sebagian ataupun keseluruhan is buku dengan cara apapun tanpaizin tertulis dari penerbit.

Perpustakaan Nasiona: Katalog Dalam Terbitan (KDT)

Andryan

Lembaga Kepresidenan: Sejaran dan Dinamika dalam Sistem Ketatanegaraan Indonesial

Penyusun, Andryan - Cet. 1 - Malang: Setara Press, 2020

$\mathrm{xii}+114 \mathrm{hlm}$; $15,5 \mathrm{~cm} \times 23 \mathrm{~cm}$

1. Kekuasaan Eksekutif-Presiden
I. Judul
II. Perpustakaan Nasiona 
Guru yang telah memberi bimbingan dan nasihat, Dari murid yang mempersembahkan buku ini untuk guru:

Yang Terpelajar dalam Usia90 Tahun

$$
\text { Prof. Dr. M. Solly Lubis, S.H. }
$$




\section{Pengantar Penulis ...}

Puji dan syukur penulispanjatkan kehadi rat Allah Swt, atas segala rahmat-Nya sehinggapenulisan buku LembagaKepresidenan: Sijarah dan Dinamikadalam Sistem Ketatanegaraan Indonesia, dapat penulis sel esaikan. Selawat beriring salam tidak lupa kita hadiahkan kepada junjungan suri tauladan kita, Nabi Besar Muhammad Saw, peran besar beliau dalam mengangkat derajat manusia menuju alam terang benderang berupailmu pengetahuan yang bermanfaat.

Lembaga Kepresidenan (Presidential institution) di Indonesia dapat disandingkan dengan lingkungan jabatan ( $a m b t)$ dan pejabat (ambtsdrager). Sedangkan, dalam bahasa asing untuk lingkungan jabatan digunakan istilah Presidency, dan sebagai pejabat digunakan istilah President. Jabatan presiden dikenal di EropaketikaPrancispada era Republik Kedua Prancis (1848-1851) menunjuk Louis Napoleon Bonaparte sebagai Presiden. Namun, setahun kemudiadiubah statusnya menjadi Kaisar Napoleon III (1852) hingga Prancis ditaklukkan Jerman (1879) dan kemudian kembali menjadi LembagaKepresidenan padaeraRepublik KetigaPrancis(1875-1940). LembagaKepresidenan juga secararesmi dikenal oleh masyarakat Internasional ketikaAmerika memilih GeorgeWashington sebagai Presiden AS1789 sampai 1797. 
Di Indonesia, sejak awal kemerdekaan, Lembaga Kepresidenan menjadi satu-satunya lembaga N egara yang pembentukannya tidak diatur dengan undang-undang tertentu dan hanyadal am batang tubuh Undang-undang Dasar sebelum terjadinya Amandemen terhadap Undang-undang Dasar Tahun 1945. Oleh karena itu, Lembaga Kepresidenan lazim disebut sebagai masa "executive heavy". Setelah amandemen atas Undang-undang D asar Tahun 1945, mulai terjadi perubahan yang sangat mendasar terkait dengan lembagakepresidenan, yang lazim di sebut sebagai pergeser an kekuasaan eksekutif yang "executive heavy" menjadi "legisdative heav".

Kedudukan, tugas, dan wewenangnya, Lembaga Kepresidenan dipimpin oleh seorang Presiden dan seorang Wakil Presiden. Pada masa sesudah amandemen UUD 1945, terdapat pembedaan kedudukannya (dalam hal ini kedudukan Presiden), Presiden berkedudukan sebagai Kepala Negara dan sebagai Kepala Pemerintahan. Struktur UUD 1945 memberikan pengaturan yang dominan terhadap Lembaga Kepresidenan, tidak hanya jumlah pasal maupun kekuasaannya. UUD 1945 memberikan kedudukan yang kuat kepada Lembaga Kepresidenan, baik dalam kekuasaan eksekutif (kekuasaan menjalankan pemerintahan), legislatif (kekuasaan membentuk peraturan perundangundangan), sertayustisial (kekuasaan yang berkaitan dengan penegakan hukum (grasi, amnesti, dan abolisi).

Penulismenyadari bahwapenulisan buku ini masi $\mathrm{h}$ jauh dari kata sempurna. $\mathrm{Hal}$ ini disebabkan keterbatasan ilmu dan pengalaman dari penulis. Oleh karenanya, penulisberharap kritik dan saran yang bersifat membangun, guna penyempurnaan buku ini ke arah yang lebih baik. Akhirnya penulis berharap buku yang sangat sederhana ini kiranya dapat memberikan nilai manfaat bagi parapembaca

Medan, Mei 2020

Penulis 


\section{Pengantar Penerbit ...}

Pada hakikatnya, Pemilihan Presiden dan Wakil Presiden secara langsung merupakan upaya mewujudkan kedaulatan rakyat melalui proses penentuan kepemimpinan nasional. Dalam sejarah ketatanegaraan di Indonesia, pengaturan pemilihan Presiden dan Wakil Presiden sering berubah-ubah dari masakemasa, sedangkan pengaturan kedudukan Presiden dan Wakil Presiden yang secara bersama-sama disebut sebagai Lembaga Kepresidenan Indonesia diatur di dalam UUD 1945. Kedudukan lembaga ini sesungguhnyamemiliki sejarah yang panjang sejalan dengan sejarah Indonesia itu sendiri. Sejarah panjang ini dimulai sejak ditentukannya konstitusi negara Indonesia pada 18 Agustus 1945, sehari setelah pembacaan naskah proklamasi, yang di dalamnya juga mengatur tentang kepemimpinan nasional.

Sebagaiman diakui oleh penulis buku ini, bahwa pengaturan tentang kelembagaan kepresidenan tidak diatur secara khusus dal am sebuah undang-undang melainkan hanya batang tubuh Undangundang Dasar sebelum terjadinya amandemen terhadap UndangUndang D asar Tahun 1945.

Namun demikian, upayauntuk mengatur lembagakepresidenan dal am sebuah undang-undang sudah dilakukan sejak tahun 2001 dan hingga saat ini belum menemukan titik terang. Upayatersebut berupa 
Rancangan Undang-Undang (RUU) Lembaga Kepresidenan yang sudah "melewati" beberapa Presiden, mulai dari KH. Abdurrahman Wahid, Megawati, Susilo Bambang Yudhoyono, hingga Joko Widodo. Dan, biasanya, kembali muncul tatkala menjelang Pemilihan Umum dan tenggelam tibatibaketikaproses Pemilu sudah selesai. Salah satu al asan tidak segeradisahkannya RUU ini karenamasi adanyatarik ulur antara Pemerintah dan DPR yang masing-masing mengusulkan draf RUU.

Pengaturan tentang Lembaga Kepresidenan -melalui UUsesungguhnya dapat dimaknai sebagai "angin segar" dalam membangun kesatuan antaraPresiden, Wakil Presiden, besertajaj arannyatermasuk pembantu presiden yang dal am hal ini adalah menteri-menteri negara $\mathrm{Hal}$ ini penting untuk memastikan ruang lingkup dalam pengaturan tugas, wewenang, serta hubungannya mencakup seluruh bagian dari lembagakepresidenan. Adanyapengaturan tentang lembagakepresidenan ini sesungguhnyajuga berguna untuk mengelaborasi lebih jauh batasbatastugas pokok dan fungsi Presiden yang diberikan oleh UUD 1945.

Buku yang ditulisoleh Mas Andryan ini hendak mengupastentang sejarah dan dinamika perkembangan lembaga kepresidenan dalam ketatanegaraan Indonesia Uraian sjarah dan dinamikaperkembangan ini ditulis secara sistematis dalam enam bagian, yaitu Lembaga Kepresidenan di Indonesia (Bagian 1), Jabatan Presiden (Bagian 2), Pengisian Jabatan Presiden (Bagian 3), Kekuasaan Presiden dalam UUD 1945 (Bagian 4), Pemberhentian Presiden (Bagian 5), dan Lembaga Penasi hat Presiden (Bagian 6). Pemilihan enam bagian ini bukan tanpaalasan. Penulis sepertinya mengikuti alur dan sistematika pembahasan yang ia berikan dalam perkuliahan ketika mengajar di Fakultas Hukum UniversitasMuhammadiyah SumateraUtara(UMSU).

Dengan terbitnyabuku ini, redaks SetaraPress(IntransPublishing Group) menyampaikan apresiasi setinggi-tingginya karena telah mempercayakan publikasi dan penerbitan buku ini kepada penerbit kami. Semoga buku ini memberikan sumbangan yang berarti bagi perkembangan ilmu pengetahuan hukum di tanah air.

Mari, rebut perubahan dengan membaca! 


\section{Daftar Isi ...}

Pengantar Penulis_ vi

Pengantar Penerbit _ viii

Bagian 1. Lembaga Kepresidenan _ 1
A. Sejarah LembagaKepresidenan _ 1
B. DinamikaLembagaKepresidenan_6
C. Sstem Pemerintahan di Indonesia_ 9

Bagian 2. Jebatan Presiden 19
A. Persyaratan Presiden
19
B. Masa Jabatan Presiden _24
C. Presiden Berhalangan__25
D. Pertanggungjawaban Presiden 30

\section{Bagian 3. Pengisian Jebatan Presiden _ 33}
A. MasaDemokras Parlementer (1945-1959) _ 35
B. MasaDemokras Terpimpin (1959-1966) _ 41
C. MasaDemokras Pancasila(1966-1998) _ 42
D. MasaDemokrasi Langsung (1998-Saat Ini) _ 46

Bagian 4. Kekuasaan Presiden 65
A. Kekuaasaan dalam Bidang Pemerintahan 66
B. Kekuasaan dalam Bidang Legi ias 71 
C. Kekuasaan dalam Bidang Yustisia _ 76

D. Kekuasaan dalam Bidang Pertahanan dan Keamanan _ 79

E. Kekuasaan dalam Bidang Luar Negeri __ 82

Bagian 5. Pemberhentian Presiden _ 84
A. ImpeachmentPresiden
87
B. Mekanisme /mpeachment di Mahkamah Konsitus 89

Bagian 6. Lembaga Penasihat Presiden _ 95
A. Sejarah Penasihat Presiden Indonesia_ 95
B. MemorabiliaDewan Pertimbangan Agung _ 100
C. Peran dan Fungsi Dewan Pertimbangan Presiden dalam UUD 1945 102

Daftar Pustaka_ 108

Tentang Penulis _ 113 